The Israeli Journal of Aquaculture - Bamidgeh •ISSN 0792-156X •IJA.73.2021.1549439, 6 pages

CCBY-NC-ND-4.0 • https://doi .org/10.46989/001c.31096

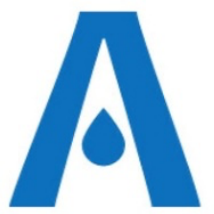

The $I J A$ is a peer-reviewed open-access, electronic journal, freely available without charge to users

Produced by the AquacultureHub non-profit Foundation Sale of $I J A$ papers is strictly forbidden

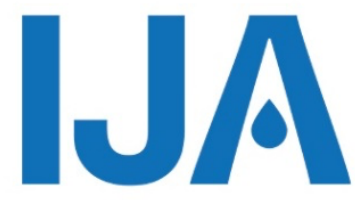

\title{
First report of Iridovirus (ISKNV) infection in Israeli mariculture gilthead sea bream (Sparus aurata) at the Mediterranean Sea
}

\section{Margarita Smirnov ${ }^{1}$, Tamir Ofek ${ }^{1}$, Hanna Hershko ${ }^{2}$ and Tetsuzan Benny Ron ${ }^{1,3}$}

\author{
${ }^{1}$ Central Fish Health Laboratory, Fisheries and Aquaculture, Ministry of \\ Agriculture and Rural Development, Nir David, 1080300 Israel \\ ${ }^{2}$ Veterinary Service, Hadera, Israel \\ ${ }^{3}$ Intensive Aquaculture Research Station, Fisheries and Aquaculture, Ministry of \\ Agriculture and Rural Development, Ginosar, Israel
}

Key words: iridovirus infection, gilthead sea bream, Sparus aurata, Mediterranean Sea, Israeli mariculture

\begin{abstract}
Megalocytiviruses have caused mass mortalities in various farmed fish species, both edible and ornamental. Infectious spleen and kidney necrosis virus (ISKNV) belongs to this family of viruses and induces lethal diseases in cultured fish. Here, we publish the first report describing this epizootic virus affecting the sea bream (Sparus aurata) in the offshore mariculture farm located in the Mediterranean Sea in Israel. The infectious agent was diagnosed with histology analysis and was identified as ISKNV by PCR.
\end{abstract}

* Corresponding author. e-mail: ritas@moag.gov.il 


\section{Introduction}

Marine aquaculture in Israel began in the early 1990s in the Gulf of Eilat, in the Red Sea. Later, cage farms were introduced to the Mediterranean Sea along the shores of Israel at the beginning of 2002 .

Those cage farms had to cope with various fish diseases (Gordin, 2003).

In Israel, systemic iridovirus infections were reported in two edible fish: the red drum Sciaenops ocellatus (Colorni and Diamant, 1995) and sea bream Sparus aurata (Paperna et al., 1982). However, its etiological agent was the lymphocystis disease virus (LCDV). It induced hypertrophied cells in the skin and sometimes in the inner organs. These cells appeared like "grape-like" aggregates and were observed easily without the microscope. However, other iridovirus infections were not found in Israeli marine cage farms (Vendramin et al., 2016; Colorni and Padrós, 2011).

At the beginning of November 2021, in two cages of a mariculture farm, mortalities were observed among sea bream, but the mortality rate was not high. The fish of 18 grams were transferred from the hatchery to cages a month before. The farm veterinarian paid attention to the unusual behavior of sea bream: the fish darkened and showed apathy, did not move at all but tried to escape in time of noise or if somebody came up to the cages. At first, such strange behavior was considered a reaction to a relatively low oxygen level$2.5 \mathrm{ppm}$ and infestation with parasites. However, the situation did not improve after management manipulation for increasing the oxygen level and medical treatment. As a result, a decision was made to immediately transport the fish to the Central Fish Health Laboratory in Nir David.

\section{Materials and Methods}

The gilthead sea bream (Figure 1) underwent necropsy with parasitological, bacterial, histological, and virology investigations (Noga,1996). Bacteriological isolations were performed on Blood TSA (Tryptic Soy Agar, Novomed) and BHI $+2 \% \mathrm{NaCl}$ (Brain heart infusion agar, Oxoid, England). Grown gram-negative bacteria were identified using API 20 NE system (Bio Merieux, Geneve, Switzerland) and sent to Hy Laboratories Ltd to identify Microorganisms by rRNA gene PCR and Sequencing.

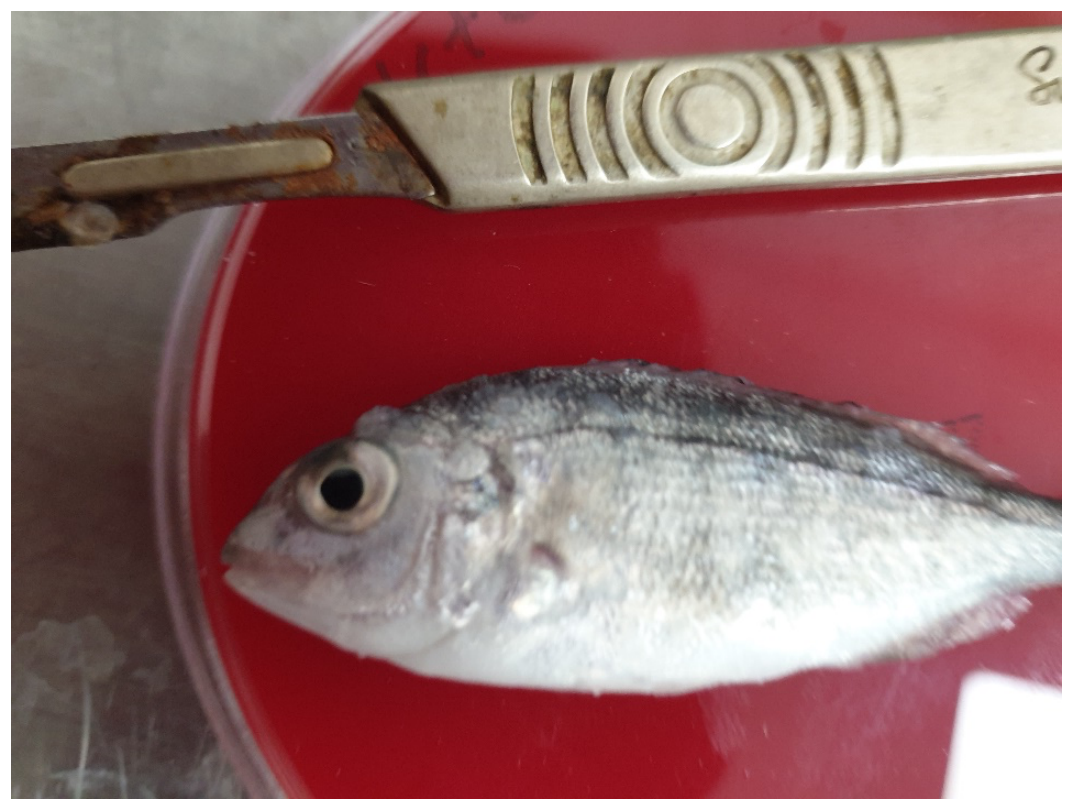

Figure 1 Gilthead sea bream specimen from the Israeli mariculture farm upon arriving at the Central Fish Health Laboratory 


\section{Histology analysis}

Fish gills, liver, kidney, spleen, heart, and intestine were fixed in $10 \%$ BNF (buffered neutral formalin) for 24 hours and processed according to routine procedures. Tissues were embedded in methacrylate (Electron Microscopy Sciences) and sectioned to 3 microns with a microtome (Leica RM2245). The sections were stained with hematoxylin and eosin.

\section{Virology}

Samples of liver were taken from fish of two cages for DNA extraction. Conventional PCR amplification was made according to the protocol for ISKNV PCR (Kurita, 2012). The PCR product was amplicon in size of 777BP.

\section{Results}

\section{Parasitology}

Moribund fish displayed petechial on the gills, inflammation in the intestine, and enlarged spleens (Figure 2). Parasitological analysis revealed a vast amount of Neobenedenia sp. (Monogenea: Capsalidae) on the fish bodies, Epitheliocystis in the gills, and myxosporidian parasites in the inner organs.

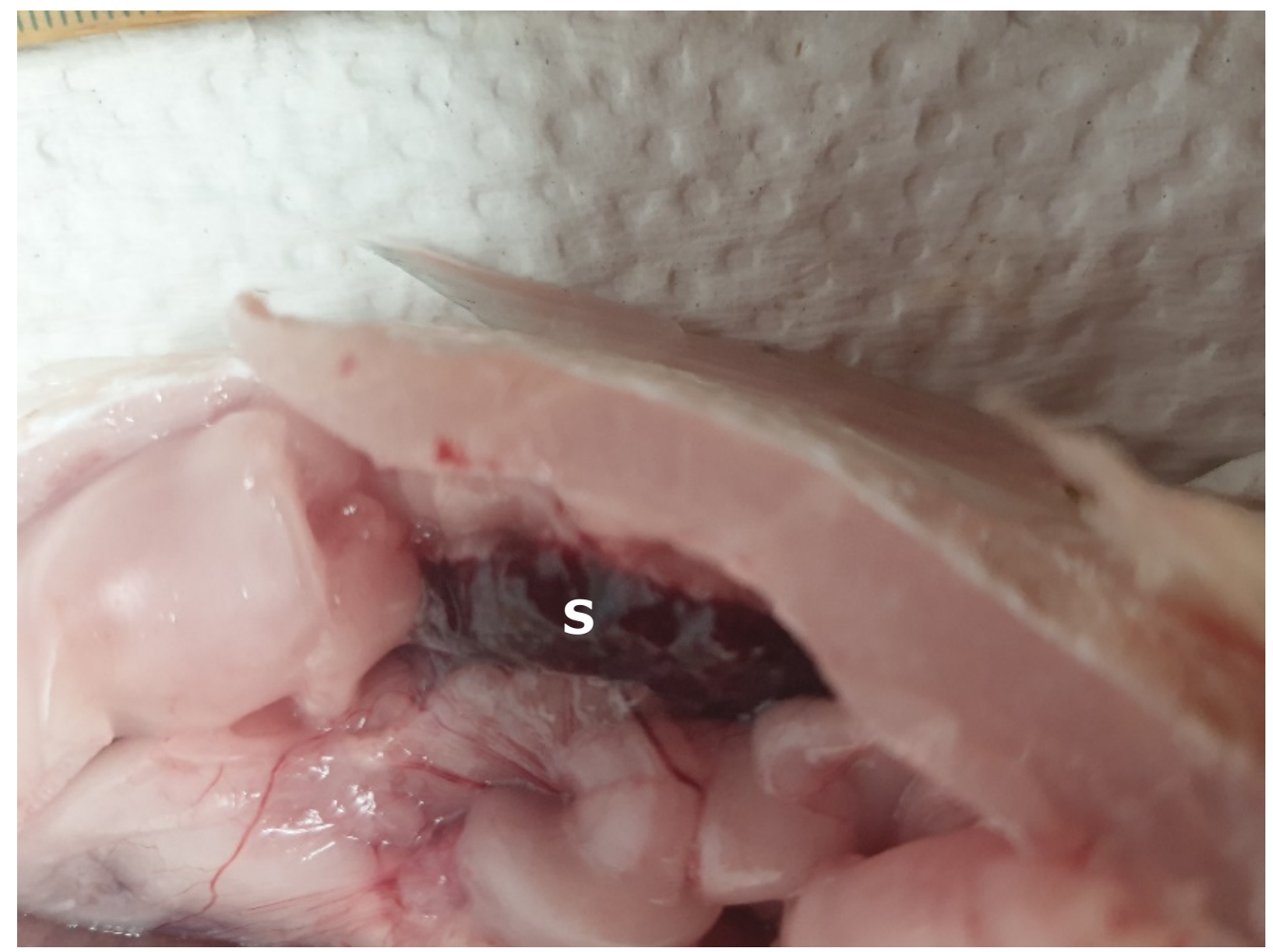

Figure 2 Moribund gilthead sea bream displayed enlarged spleens (S).

\section{Bacteriology}

The API 20 NE system's identification was insufficient. The additional confirmatory test performed by Hy Laboratories determined Vibrio harveyi ( $99 \%$ Homology) in the tested samples from the sea bream of both cages. 


\section{Histology}

The light microscopy examination of the histological section revealed acute inflammation in the intestine (Figure 3), megalocytic cells that occurred in intestinal lamina propria (Figure 4), and in the renal and splenic tissues. These cells were hypertrophic, their nuclear were fragmented, and the cytoplasm had dense basophilic matter (Figure 5) (Miyazaki, 2009).

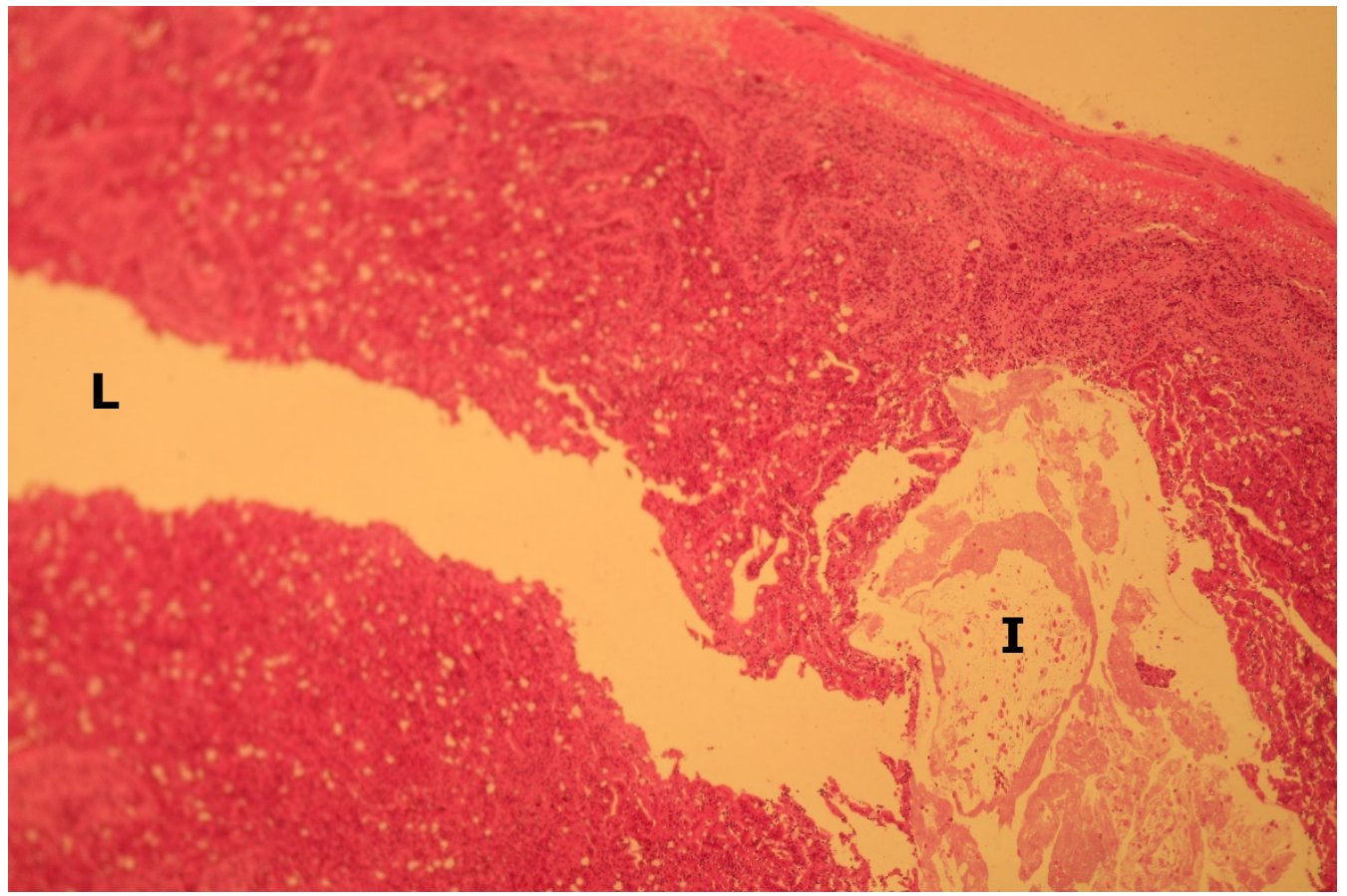

Figure 3 Light microscopy examination of the histological section revealed acute inflammation in the intestine (L-lumen; I-Inflammation).

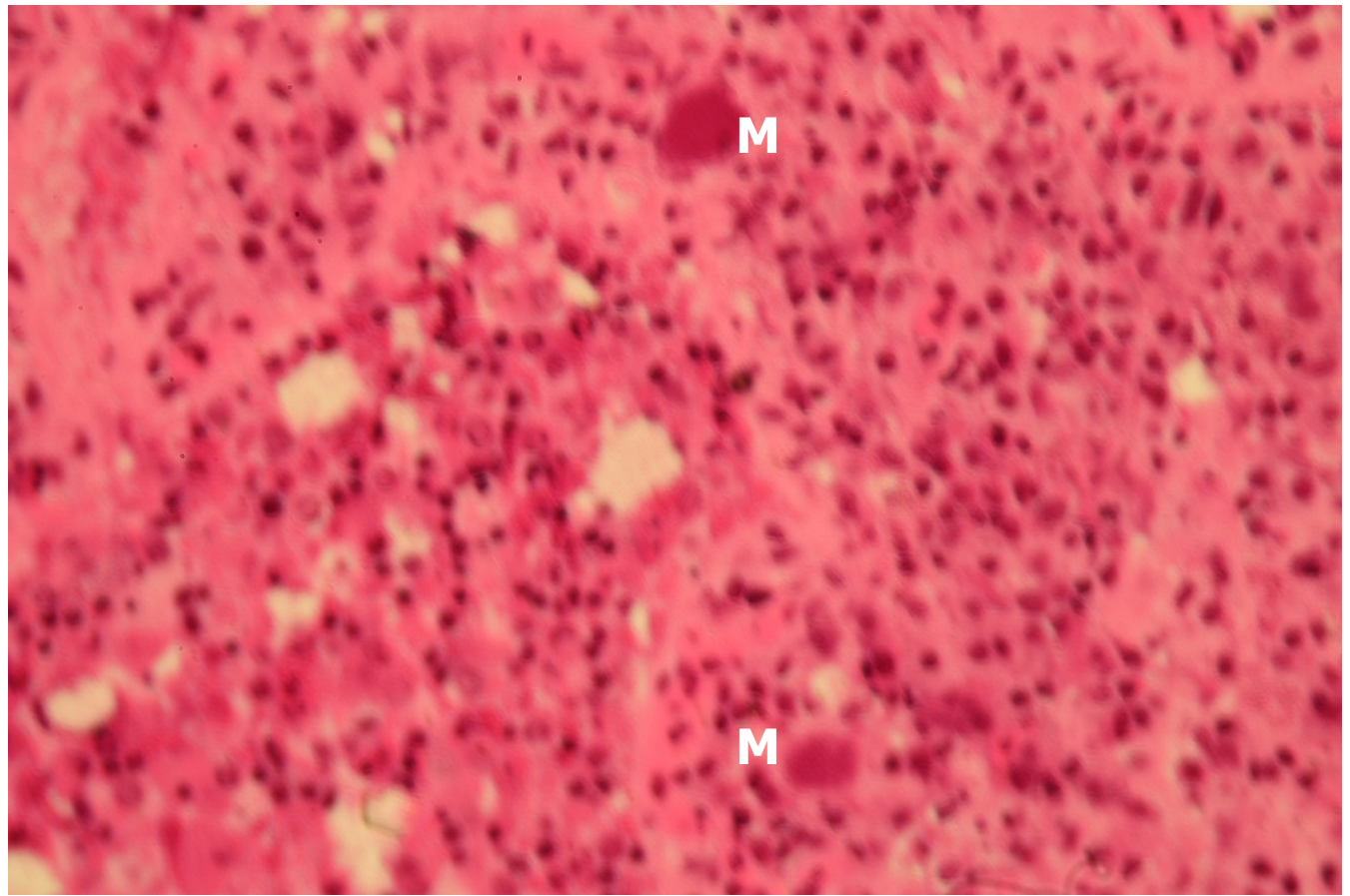

Figure 4 Light microscopy examination of the histological section revealed megalocytic cells (M) that occurred in intestinal lamina propria.

The Israeli Journal of Aquaculture - Bamidgeh •ISSN 0792-156X • IJA.73.2021.1549439 


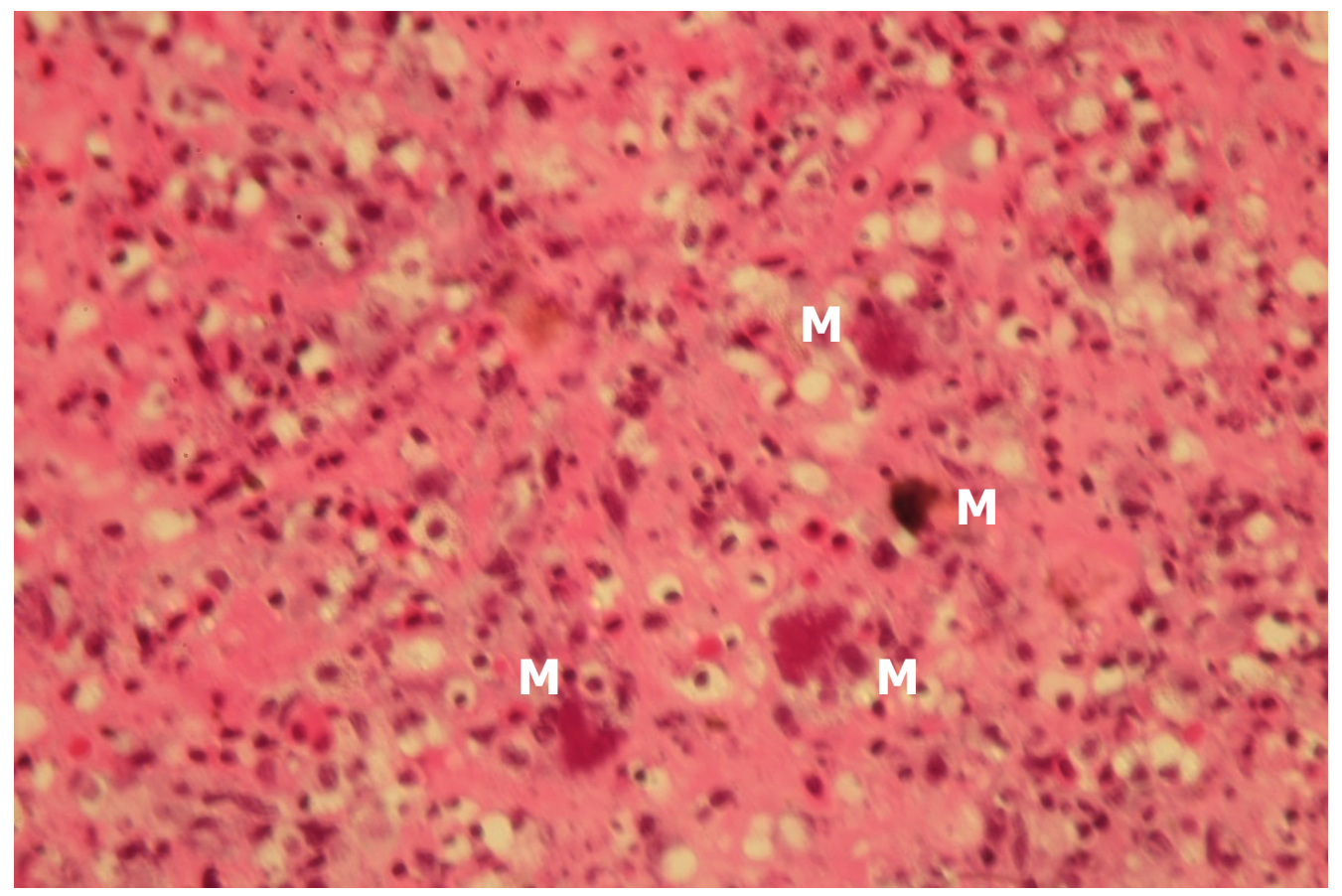

Figure 5 Light microscopy examination of the histological section revealed spleen cells that were hypertrophic (M) while their nucleuses were fragmented. The cytoplasm had dense basophilic matter.

\section{Molecular biology}

Positive PCR results were found in 4 of 8 tested liver samples. The positive tissues belonged to fish from one of the two cages (Figure 6 ).

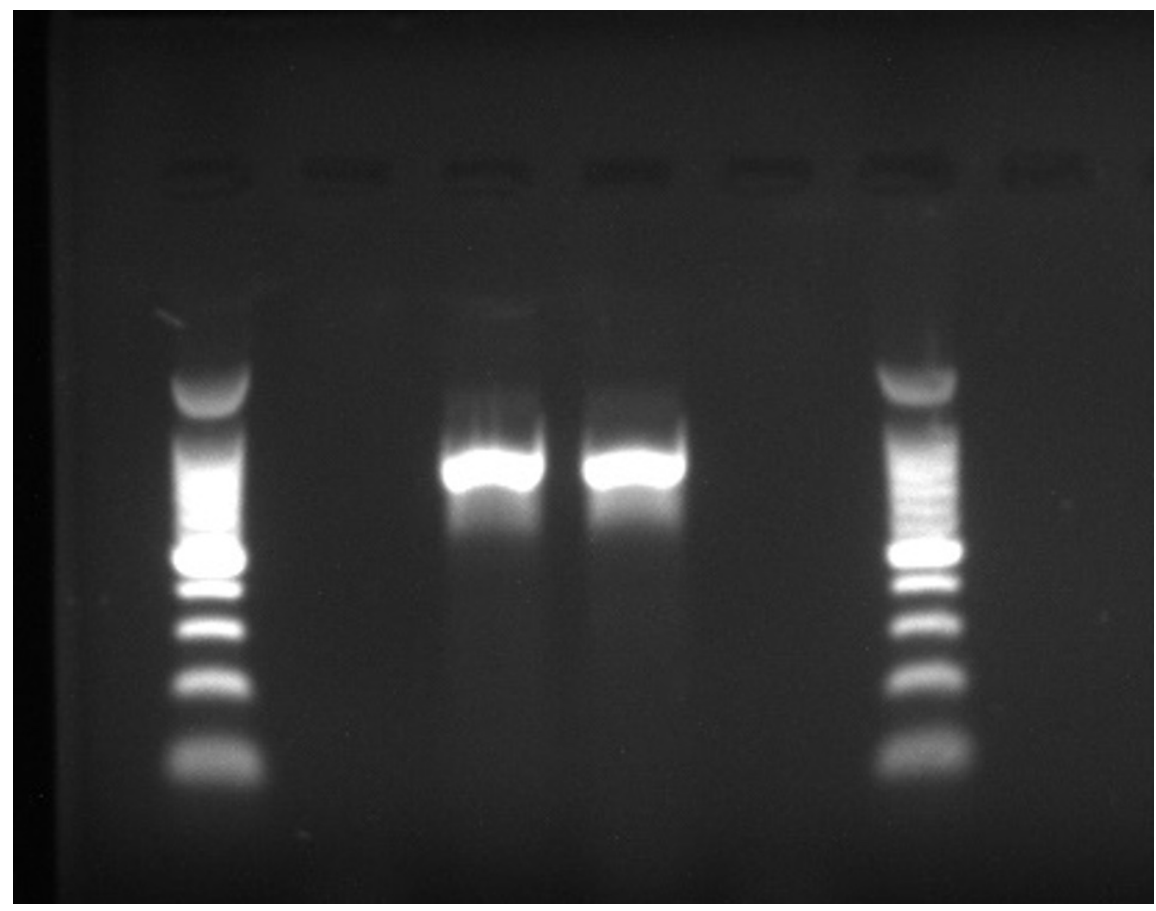

Figure 5 ISKNV positive result gel. Left to right: DNA ladder, negative sample, positive sample (777 bp size), positive control (777 bp size), negative control, DNA ladder. 


\section{Discussion}

According to histological and PCR findings, a positive diagnosis of iridovirus infection (ISKNV) was made. Here, we report the first confirmed infectious spleen and kidney necrosis virus in fish from Israel's Mediterranean Sea mariculture farm.

As far as we know, outbreaks of ISKNV have been seen mainly in the summer at a temperature above $25^{\circ} \mathrm{C}(\mathrm{M})$, but the difference of this case was when it happened -late autumn at water temperature $20^{\circ} \mathrm{C}$. The source of this virus in this specific epizootic could not be found.

ISKNV infection is a notifiable fish disease (OIE, 2021). Therefore, upon confirming the findings, the Director of the Central Fish Health Laboratory sent a report to the mariculture cage farm veterinarian, and the Veterinary Services of the Ministry of Agriculture and Rural Development in Israel. As a result, the farm veterinarian also reported to the Veterinary Services of the Ministry of Agriculture and Rural Development in Israel.

\section{Author Contribution}

Margarita Smirnov - Parasitology and histology analysis and manuscript preparation. Tamir Ofek - Molecular virology analysis.

Hanna Hershko - Preliminary fish examination, reporting of fish behavior, and recommendation further investigation by the Central Fish Health Laboratory (CFHL). Tetsuzan Benny Ron - Manuscript preparation and editorial. Director of CFHL.

\section{References}

Colorni, A. and Diamant, A. 1995. Splenic and cardiac lymphocystis in the red drum, Sciaenops ocellatus (L.). Journal of Fish Diseases (United Kingdom). (1), 38-45. https://doi.org/10.1111/j.1365-2761.1995.tb00339.x

Colorni, A. and Padrós, F. 2011. Diseases and health management. Sparidae, 321-357. https://doi.org/10.1002/9781444392210.ch10

Gordin H. 2003. Mariculture in Israel. Israeli Journal of Aquaculture - Bamidgeh, 55 https://doi.org/10.46989/001c.20359

Kurita, J. and Nakajima, K. 2012. Megalocytiviruses. Viruses, 4(4), 521-538. https://doi.org/10.3390/v4040521

Noga, E.J. 1996. Fish Disease: Diagnosis and Treatment. St. Louis, MO Mosby-Year Book, Inc. 17-26. ISBN: 978-0-813-80697-6

OIE Aquatic Animal Health Code, 2021. 3rd Edition 2021. ISBN 978-92-95115-52-1

Paperna, I., Sabnai, I.H. and Colorni, A. 1982. An outbreak of lymphocystis in Sparus aurata L. in the Gulf of Aqaba, Red Sea. Journal of Fish Diseases, 5(5), 433-437.

Miyazaki, T. 2009. Color Atlas of Fish Histopathology (Vol.2). Shin-Suisan Shinbun-Sha. Ltd.

Vendramin, N., Zrncic, S., Padrós, F., Oraic, D., Le Breton, A., Zarza, C. and Olesen, N.J. 2016. Fish health in Mediterranean Aquaculture, past mistakes and future challenges. Bulletin of the European Association of Fish Pathologists, 36. 